\title{
Legal Advocacy as a Strategy for Agrarian Activism in Indonesia
}

\author{
Iqra Anugrah $^{1}$ \\ \{iqra@ cseas.kyoto-u.ac.jp\} \\ ${ }^{1}$ JSPS Postdoctoral Fellow, Center for Southeast Asian Studies, Kyoto University, Japan
}

\begin{abstract}
This article aims to analyze the trajectory of legal struggle for agrarian justice in contemporary Indonesia. Author identifies several currents of legal advocacy in agrarian activism in Indonesia. First position is the liberal view of the rule of law. The second position is the structural approach to legal advocacy, promoted by the next generations of activist lawyers and advocates who integrate class analysis and community organizing in their work. The third strand is what author would call as the populist view of legal advocacy that sees legal struggle as a part of the broader class-based or populist politics.
\end{abstract}

Keywords: Legal Advocacy, Legal Struggle, Agrarian Activism

\section{Introduction}

Appealing to the rule of law has always been part of agrarian and social movement advocacy in Indonesia and other parts of the world. In doing so, ordinary citizens and activists legitimize their claims of grievances. In China, for example, peasants and rural citizens use the Chinese state's own rhetoric and legal provisions to fight corrupt local officials, expand the scope of popular participation, and gradually advance their rights [1]. In the United States (US), the civil rights movement pressured the American state and society by urging them to live up to the spirit of the US constitution. In Indonesia, peasant communities and agrarian activists have been using legal advocacy as a major arsenal in the struggle for agrarian justice, at least since the 1960s. Though actors involved in environmental and agrarian movements in Indonesia have expanded and diversified their advocacy strategies, they still utilize legal advocacy as a tool for community organizing and promoting a wide range of rural interests - from land rights to identity recognition. Legal advocacy can take various forms, such as calling for the consistent implementation of the existing laws and regulations, pushing for the fulfillment of legally-guaranteed rights, and proposing new laws, among others. But in contemporary Indonesian context, these multiple forms of legal advocacy share two main characteristics, namely 1) support for the rule of law and 2) emphasis on societal or popular mobilization as a backbone for legal advocacy.

Here, I aim to analyze the trajectory of legal struggle for agrarian justice in contemporary Indonesia. Mapping its evolution since the height of agrarian populism of the 1960s until today, I identify several currents of legal advocacy in agrarian activism in Indonesia. First is the liberal view of the rule of law, espoused by the pioneers of Indonesia's Legal Aid Foundations (Lembaga Bantuan Hukum, LBH), centered around the notion of the protection of individual citizen rights against arbitrary state power. [2] The second position is the structural approach to legal advocacy, promoted by the next generations of activist lawyers and advocates who integrate class analysis and community organizing in their work. The third strand is what I would call as the populist view of legal advocacy that sees legal struggle as a part of the broader class-based or populist politics.

\section{Discussion}

Historically, the initial major breakthrough in legal struggle for agrarian justice originated from the populist strand, represented by left-leaning peasant and rural labor unions. During the 
Guided Democracy period (1959-1965) it was the left-leaning Indonesian Peasants' Front (Barisan Tani Indonesia, BTI) and Plantation Workers Union (Sarekat Buruh Perkebunan Republik Indonesia, SARBUPRI) who were at the forefront of political struggle for the rights of the peasantry and plantation workers [3]. Through mass mobilization, they championed the consistent implementation of the 1959 Basic Share-Tenancy Law (Undang-undang Pokok Bagi Hasil, UUPBH) and the 1960 Basic Agrarian Law (Undang-undang Pokok Agraria, UUPA) that mandated land redistribution, capping of landholding size, and redefinition of tenancy into ownership rights. Tragically, the 1965 anti-communist purge systematically excised the leftistpopulist tradition from Indonesia's body politic and reversed the achievements of land reform campaign. In the near-absence of this tradition in post-1965 political landscape, the liberal view of legal advocacy burst into Indonesia's civil society scene. Albeit moderate, this strand of legal activism helped in setting the motion for the slowly burgeoning opposition under the New Order authoritarian regime.

The broader change of rural political economy during the 1970s and 1980s played a significant part in the progressive shift of legal advocacy in agrarian activism. This was the period when the New Order regime intensified its exploitation of land and forest resources, a process legitimized via the issuance of commercial lease rights (Hak Guna Usaha, HGU) and other regulations justifying corporate expansion to the countryside [4]. This led to the intensification of land grabbing by state and corporate authorities at the expense of rural communities. Soon LBHs, lawyers, activists, and students participated in the new wave of legal advocacy for various local agrarian struggles [5]. Informed by the structural approach of legal advocacy, legal practitioners, activists, and rural community leaders of this period aimed to solve land dispute cases and, equally important, rejuvenate mass politics in rural areas. Later, democratization in 1998 paved the way for a more assertive, contestational mode of agrarian activism. In early 2000s, local peasant unions sprang up in districts affected by enduring agrarian conflicts. This post-authoritarian wave of agrarian activism also facilitated the resurgence of populist tendency in legal advocacy for agrarian justice. This means legal advocacy for agrarian justice is no longer the exclusive domain of lawyers and middle-class activists. Ordinary community members and peasant leaders now have become more involved in the day-to-day process of legal advocacy. In my field experience in various districts (North Bengkulu, Ciamis, and Bulukumba, among others), I found that they take up a variety of roles in this process: as a chronicler of events and legal documents, an educator for their fellow neighbors, and a local paralegal, to name a few. Various rural communities and organizations along with their activist allies have also combined legal advocacy with more disruptive tactics, such as mass demonstrations. It has become a common strategy, for example, to protest local authorities to issue a copy of HGU agreements for communities affected by the expansion of HGU plantations.

Some rural social movements take one step further by institutionalizing their legal advocacy works. The Sundanese Peasant Union (Serikat Petani Pasundan, SPP) have established its own LBH to advance its legal struggle and provide legal service for other marginalized rural communities in Ciamis and Tasikmalaya [6][7]. In Bulukumba, the indigenous Kajang people, local peasant communities, and some other civil society organizations have succesfully pushed the drafting and issuance of regional bylaw (peraturan daerah, perda) recognizing the rights of the Kajangs as indigenous people, especially concerning ancestral land and community forest [8]. In Demak, women in fishing communities have been actively participating in various paralegal works for fishers' rights and gender equality [9]. While the recent resurgence of legal populism might be different from that of BTI and Sarbupri, it nonetheless brings back the element of mass participation and progressive popular politics into legal advocacy for agrarian activism. Seen from that perspective, one can say that post-1965 agrarian movements in Indonesia have come a long way. 


\section{Conclusion}

The many expressions of legal advocacy strategies for agrarian justice in Indonesia deserve a closer scrutiny. One way to do so is to assess achievements and limitations of these strategies. One should also put these advances in movement strategies in the broader historical and comparative contexts. Looking at qualitative evidence from various recent and historical case studies in Indonesia and beyond, it is safe to say that for legal advocacy to succeed, it must integrate community participation and mass mobilization. In this context, the liberal form of legal activism might be insufficient to get pro-democratic and agrarian justice agenda codified into laws and implemented as policies. While its emphasis on legal impartiality and individual rights is appreciated, it is not sufficient to expand democratic spaces and citizens' rights especially in socioeconomic realms.

This is why the shift to structuralist and populist approaches in legal advocacy for agrarian justice should be welcomed. An important lesson from the experience of BTI, SARBUPRI, and many other rural community organizations is that the rule of law and policy change do not fall from the sky. There is a higher chance for legal advocacy to bear fruits if it is accompanied with mass pressure from below. There is an empirical basis for this claim: quantitative and crossnational evidence show that major political reforms, such as democratization, occur because of the disruptive capacity of non-elite actors [9].

We should also look at the achievements of legal advocacy for agrarian justice with caution. Here, it is important to remember that the adoption of laws advocated or proposed by agrarian activists and rural communities is the same as their implementation. One should not conflate policy formulation with its implementation. I therefore remain skeptical with the claim regarding the increasing influence of activist groups and community leaders in Indonesia's elite-dominated politics. [11] To date, the mandates of UUPA and UUPBH have not been implemented consistently. Furthermore, there has been no major policies addressing land grabbing cases across Indonesia. Nevertheless, as cliché as it may be, the idealized notion of the rule of law still has the potential to serve as a battle cry for marginalized rural communities and agrarian activists in their struggle for agrarian justice in an unequal market society. The downtrodden can strategically make use of the idea of legal impartiality, however feeble and Janus-faced it is. This is the point of the British social historian, E. P. Thompson (1975). [12] When armed with mass mobilization and democratic community organization, perhaps clinging to such an old notion might not be a bad idea after all.

\section{References}

[1] O'Brien, Kevin J., and Lianjing Li. 2006. Rightful Resistance in Rural China. New York: Cambridge University Press.

[2] Lev, Daniel S. 2000. Legal Evolution and Political Authority in Indonesia: Selected Essays. The Hague: Kluwer Law International

[3] White, Ben. 2016. "Remembering the Indonesian Peasants' Front and Plantation Workers' Union (1945-1966)." Journal of Peasant Studies 43 (1): 1-16.

[4] Bachriadi, Dianto. 2010. "Between Discourse and Action: Agrarian Reform and Rural Social Movements in Indonesia post-1965." PhD Thesis, School of International Studies, Flinders University, Adelaide.

[5] Anugrah, Iqra. 2019. "Movements for Land Rights in Democratic Indonesia." In Activists in Transition: Progressive Politics in Democratic Indonesia, edited by Thushara Dibley and Michele Ford, 79-97. Ithaca: Cornell University Press.

[6] Rahman, Iman S. 2020. SPP Ciamis Salurkan Hasil Bumi untuk Buruh Perantau Korban Covid-19 di Jakarta. April 11. Accessed June 30, 2020. https://www.radartasikmalaya.com/spp-ciamis-salurkan-hasil-bumi-untuk-buruh-perantaukorban-covid-19-di-jakarta/. 
[7] Respati. 2020. LBH SPP Sesalkan Oknum RW di Garut yang Intimidasi Warga Pengharap Bantuan. May 28. Accessed June 30, 2020. https://www.gosipgarut.id/read/2020-14458/lbhspp-sesalkan-oknum-rw-di-garut-yang-intimidasi-warga-pengharap-bantuan.html.

[8] van der Muur, Willem, and Adriaan Bedner. 2016. "Traditional Rule as 'Modern Governance': Recognising the Ammatoa Kajang Adat Law Community." Mimbar Hukum 28 (1): $149-161$.

[9] Pratiwi, Andi M. 2017. "Masnuah, Pejuang Hak-Hak Perempuan Nelayan." Jurnal Perempuan 22 (2): 377-383.Lev, Daniel S. 1976. "Origins of the Indonesian Advocacy." Indonesia 21: 134-169.

[10] Usmani, Adaner. 2018. "Democracy and the Class Struggle." American Journal of Sociology 124 (3): 664-704.

[11] Mietzner, Marcus. 2013. "Fighting the Hellhounds: Pro-democracy Activists and Party Politics in Post-Suharto Indonesia." Journal of Contemporary Asia 43 (1): 28-50.

[12] Thomspon, Edward P. 1975. Whigs and Hunters: The Origin of the Black Act. New York: Pantheon Books. 